\title{
Article \\ Phytochemical Analysis and In Vitro Cytotoxic Activity against Colorectal Adenocarcinoma Cells of Hippophae rhamnodies L., Cymbopogon citratus (D.C.) Stapf, and Ocimum basilicum L. Essential Oils
}

\author{
Alina Dolghi 1,2, ${ }^{\text {, Roxana Buzatu }}{ }^{3,+}+\mathbb{D}$, Amadeus Dobrescu 4,*价, Flavius Olaru 5,*, Grigore Alexandru Popescu 4 , \\ Iasmina Marcovici ${ }^{1,2}$, Iulia Pinzaru ${ }^{1,2}$ (D), Dan Navolan ${ }^{5}$ (D), Octavian Marius Cretu ${ }^{4}$, Iuliana Popescu ${ }^{6}$ \\ and Cristina Adriana Dehelean ${ }^{1,2}$
}

check for updates

Citation: Dolghi, A.; Buzatu, R.; Dobrescu, A.; Olaru, F.; Popescu, G.A.; Marcovici, I.; Pinzaru, I.; Navolan, D.; Cretu, O.M.; Popescu, I.; et al. Phytochemical Analysis and In Vitro Cytotoxic Activity against Colorectal Adenocarcinoma Cells of Hippophae rhamnodies L., Cymbopogon citratus (D.C.) Stapf, and Ocimum basilicum L. Essential Oils. Plants 2021, 10, 2752. https://doi.org/10.3390/ plants10122752

Academic Editor: Cinzia Sanna

Received: 10 November 2021 Accepted: 10 December 2021 Published: 14 December 2021

Publisher's Note: MDPI stays neutral with regard to jurisdictional claims in published maps and institutional affiliations.

Copyright: (c) 2021 by the authors. Licensee MDPI, Basel, Switzerland. This article is an open access article distributed under the terms and conditions of the Creative Commons Attribution (CC BY) license (https:/ / creativecommons.org/licenses/by/ $4.0 /)$.
1 Department of Toxicology and Drug Industry, Faculty of Pharmacy, "Victor Babes" University of Medicine and Pharmacy Timisoara, Eftimie Murgu Sq. No. 2, 300041 Timisoara, Romania; dolghi.alina@umft.ro (A.D.); iasmina.marcovici@umft.ro (I.M.); iuliapinzaru@umft.ro (I.P.); cadehelean@umft.ro (C.A.D.)

2 Research Center for Pharmaco-Toxicological Evaluations, "Victor Babes" University of Medicine and Pharmacy Timisoara, Eftimie Murgu Sq. No. 2, 300041 Timisoara, Romania

3 Department of Dental Aesthetics, Faculty of Dental Medicine, "Victor Babeș" University of Medicine and Pharmacy Timisoara, Eftimie Murgu Sq. No. 2, 300041 Timișoara, Romania; drbuzaturoxana@gmail.com

4 Department of Surgery, Faculty of Medicine, "Victor Babes" University of Medicine and Pharmacy Timisoara, Eftimie Murgu Sq. No. 2, 300041 Timisoara, Romania; grigore.popescu@umft.ro (G.A.P.); octavian.cretu@umft.ro (O.M.C.)

5 Department of Obstetrics-Gynecology, Faculty of Medicine, "Victor Babes" University of Medicine and Pharmacy Timisoara, Eftimie Murgu Sq. No. 2, 300041 Timisoara, Romania; navolan@umft.ro

6 Department of Soil Sciences, Faculty of Agriculture, Banat University of Agricultural Sciences and Veterinary Medicine “King Michael I of Romania", Calea Aradului 119, 300645 Timişoara, Romania; iuliana_popescu@usab-tm.ro

* Correspondence: dobrescu.amadeus@umft.ro (A.D.); olaru.flavius@umft.ro (F.O.)

+ Shared first author's position.

Abstract: Colorectal carcinoma (CRC) is one of the most frequently diagnosed cancer types with current deficient and aggressive treatment options, but various studied alternative therapies are able to efficiently contribute to its management. Essential oils (EOs) contain valuable compounds, with antibacterial, anti-inflammatory, and anticancer properties, which might serve as effective solutions in CRC prophylaxis or treatment. The aim of the present work was to evaluate the phytochemical composition and in vitro biological activity of essential oils derived from Hippophae rhamnoides (Hr_EO), Cymbopogon citratus (Cc_EO), and Ocimum basilicum (Ob_EO) species on HT-29 and Caco-2 human colorectal adenocarcinoma cell lines. The main compounds identified by GC-MS analysis were estragole (Hr_EO,Ob_EO), alpha- and beta-citral (Cc_EO). All tested EOs exerted a dose-dependent cytotoxicity on both cell lines by reducing the cell viability, especially in the case of Cc_EO, where at $75 \mu \mathrm{g} / \mathrm{mL}$ the viability percentages reached the values of $62.69 \%$ (Caco-2) and $64.09 \%$ (HT-29), respectively. The nuclear morphology evaluation highlighted significant dysmorphologies on both lines after their treatment with EOs at $75 \mu \mathrm{g} / \mathrm{mL}$.

Keywords: essential oils; tumor cells; viability; nuclear morphology; migratory capacity

\section{Introduction}

Colorectal carcinoma (CRC) represents the fourth most frequently diagnosed malignancy, and the third leading cause of cancer-related deaths in adults worldwide. According to the most recent GLOBOCAN data, the estimated CRC incidence is 19.5/100,000 inhabitants, and following an ascending trend line [1]. Although the pathogenetic mechanisms leading to CRC are not fully understood [2], several risk factors have been strongly correlated to its onset, such as age, gene mutations (i.e., APC, KRAS, TP53), pre-existent 
digestive pathologies (e.g., inflammatory bowel disease, Crohn's disease), lifestyle habits (e.g, diet, sedentarism, smoking, alcohol consumption), and dysbiosis [3].

Curative treatment regimens vary from surgical resection in incipient stages to neoadjuvant therapy in advanced CRC forms, referring to radiotherapy and chemotherapy medication (e.g., leucovorin calcium, 5-Fluorouracil, oxyplatine, fluoropyrimidine, capecitabine) [4]. Although the current chemotherapy significantly have been shown to increase patients' survival rate, improve the $\mathrm{CRC}$ outcome, and reduce the disease recurrence to a considerable extent, severe adverse events and drug-resistance are important disadvantages limiting this treatment option [5]. Therefore, the development of alternative therapy approaches is required. Medicinal plants play a substantial role in the prophylaxis and treatment of various types of cancer [6], and stand as an inexhaustible resource for phytochemicals possessing anti-CRC properties due to their antioxidant, anti-inflammatory, pro-apoptotic, and proautophagic effects [7]. Essential oils (EOs) are volatile, aromatic, hydrophobic, plant-derived products traditionally used in therapy for their broad spectrum of biological activities (e.g., sedative, antiseptic, anti-inflammatory, antimicrobial, spasmolytic, and anti-cancer) [8], which might offer substantial benefits in the management of colonic pathology [9].

Hippophae rhamnoides L. (sea buckthorn) is a medicinal plant widely recognized for exerting anti-inflammatory, antioxidant, anti-atherosclerotic, and anti-cancer activities due to the abundance of bioactive compounds found in its berries, leaves, roots, seeds, and oil. The anti-tumor property is mainly attributed to antioxidant compounds, such as flavonoids which offer protection against oxidative stress-induced damage and genetic mutations [10]. The composition of sea buckthorn essential oils is dominated by free fatty acids, esters, and alkanes, which print an important biological potency [11]. Several studies suggest a broad anticancer spectrum on lung, liver, breast, and blood malignancies [12-15].

Cymbopogon citratus (D.C.) Stapf or lemongrass is an aromatic herb widely exploited for its essential oil, which possesses a plethora of pharmacological effects varying from antiamebic, anti-fungal, anti-malarial and anti-bacterial to anti-oxidant and anti-inflammatory properties [16]. Recent publications refer to the anti-tumor activity of lemongrass extracts against prostate, liver, ovarian, colon, and breast carcinomas [17,18].

Ocimum basilicum $\mathrm{L}$. or basil is a plant belonging to the Lamiaceae family. Beside its traditional use for culinary purposes, basil exerts several biological activities (e.g., anti-microbial, anti-diabetic, cardio-protective, anti-inflammatory, anti-cancer, and chemopreventive) providing multiple health benefits [19].

The aim of the present work was to evaluate the phytochemical composition and investigate the in vitro anti-tumor capacity of H. rhamnoides L., C. citratus (D.C.) Stapf, and O. basilicum L. essential oils (Hr_EO, Cc_EO, and Ob_EO) as potential chemo-prophylactic or chemo-therapeutic alternatives in CRC management. To the best of our knowledge, this is the first study in the literature that investigates the anti-CRC properties of these essential oils against two human colorectal adenocarcinoma cells (Caco-2 and HT-29).

\section{Results}

\subsection{Gas Chromatography-Mass Spectrometry (GC-MS) Analysis}

In order to evaluate the phytochemical composition of commercial Hr_EO, Cc_EO, and Oc_EO, a GC-MS analysis was performed. Therefore, in Hr_EO there were 13 compounds identified (presented in Table 1), the most abundant being estragole representing $63.1 \%$ of the total oil composition. In CC_EO, the most abundant compounds among the 33 detected (displayed in Table 2) were alpha- and beta-citral, accounting for $66.2 \%$ of the total oil composition. Similarly to Hr_EO, in Ob_EO, estragole was the main abundant compound among the 31 identified, with a total percentage of $45.9 \%$. The complete composition is displayed in Table 3. 
Table 1. The main phytochemical constituents of Hippophae rhamnoides L. essential oil identified by GC-MS analysis.

\begin{tabular}{cccccc}
\hline Name & R. Time & m/z & Area & Height & Concentration \\
\hline Isobutvrvl bromide & 20.809 & TIC & 85,682 & 6956 & 11.22 \\
Estragole & 23.661 & TIC & 481,549 & 59,917 & 63.06 \\
Glycidol & 25.158 & TIC & 20,112 & 3487 & 2.63 \\
2-Propenoie acid, 2-methyl-, ethenyl ester & 29.778 & TIC & 18,940 & 1797 & 2.48 \\
(S)-2-Hydroxypropanoic acid & 30.276 & TIC & 2732 & 281 & 0.35 \\
N-Methylglycine & 30.764 & TIC & 13,019 & 897 & 1.70 \\
Propanedioic acid, oxo-, dimethyl ester & 31.172 & TIC & 8017 & 1029 & 1.05 \\
2-Methoxy-1, 3-dioxolane & 32.226 & TIC & 13,747 & 813 & 1.80 \\
Propane, 2-ethoxy & 32.600 & TIC & 1895 & 404 & 784 \\
Isopropyl Alcohol & 33.008 & TIC & 10,255 & 941 & 1.34 \\
Ethanol, 2-[2-(ethnyloxy) ethoxy]- & 33.162 & TIC & 9418 & 941 & 1.23 \\
Ethane, 1,1'-oxybis[2-methoxy] & 34.232 & TIC & 2883 & 831 & 2.99 \\
Pentandioic acid, (p-t-butylphenyl) ester & 34.553 & TIC & 15,391 & 12,088 & 9.87 \\
\hline
\end{tabular}

Table 2. The main phytochemical constituents of Cymbopogon citratus (D.C.) Stapf essential oil identified by GC-MS analysis.

\begin{tabular}{|c|c|c|c|c|c|}
\hline Name & R. Time & $\mathbf{m} / \mathbf{z}$ & Area & Height & Concentration \\
\hline .apha, -Thujene & 6.006 & TIC & 64,743 & 10,639 & 0.072 \\
\hline Bicyclo [3.1.0]hex -2-ene, 2-methyl-5-(methy) & 6.466 & TIC & 44,0792 & 41891 & 0.487 \\
\hline Camphene & 7.511 & TIC & $1,129,013$ & 136,064 & 1.247 \\
\hline beta. -Myrcene & 10.179 & TIC & 1273,812 & 163,422 & 1.407 \\
\hline Limonene & 11.283 & TIC & 2693,725 & 336,122 & 2.976 \\
\hline Ocimene (E)- & 12.219 & TIC & 284,397 & 45,290 & 0.314 \\
\hline Ocimene (Z)- & 12.712 & TIC & 164,002 & 27,220 & 0.181 \\
\hline 4-Nonanone & 14.808 & TIC & 873,286 & 143,765 & 0.965 \\
\hline 5-Hepten-2-one, 6-methyl- & 14.972 & TIC & $2,307,111$ & 355,154 & 2.549 \\
\hline Phenol, 3-methyl-5-(1-methylethyl)-, Methylca & 16.779 & TIC & 34,226 & 8564 & 0.038 \\
\hline 2-Propenoic acid, 2-methyl-, ethenyl ester & 17.253 & TIC & 40,657 & 7065 & 0.045 \\
\hline 1,6-Heptadiene, 2-methyl- & 18.953 & TIC & 192,620 & 27,349 & 0.213 \\
\hline d -Norbomanone & 19.136 & TIC & 100,006 & 17,289 & 0.110 \\
\hline Copaene & 19.610 & TIC & 61072 & 10,909 & 0.067 \\
\hline 2,2-Dimethylocta-3, 4-dienal & 19.757 & TIC & 265,918 & 29,040 & 0.294 \\
\hline Linalool & 20.796 & TIC & $2,900,499$ & 181,609 & 3.204 \\
\hline Cyclopropane, 1,1-dimethyl-2-(2-methyl-2-pro) & 21.310 & TIC & 798,964 & 80,284 & 0.883 \\
\hline Cyclopentanecarboxylic acid, 2 methyl-3-meth & 21.991 & TIC & 191,346 & 35,596 & 0.211 \\
\hline 1,7 -Octadiene, 3-methylene- & 22.149 & TIC & 76,920 & 13,393 & 0.085 \\
\hline Caryophyllene & 22.483 & TIC & $2,021,644$ & 265,029 & 2.233 \\
\hline Estragole & 23.676 & TIC & 231,331 & 26,376 & 0.256 \\
\hline beta Citral (Z)- & 24.025 & TIC & $26,167,607$ & $3,452,865$ & 28.910 \\
\hline n-menth-1-en-8-ol & 24.953 & TIC & 808,078 & 74,951 & 0.893 \\
\hline alpha Citral (E)- & 25.203 & TIC & $33,701,032$ & $4,346,928$ & 37.233 \\
\hline Geraninol acetate, (Z)- & 25.698 & TIC & $5,267,532$ & 966,974 & 5.820 \\
\hline delta Cadinene & 26.157 & TIC & 106,187 & 21,685 & 0.117 \\
\hline gamma Muurolene & 26.286 & TIC & 722,205 & 113,718 & 0.798 \\
\hline Caryophyllene oxide & 31.129 & TIC & 180,807 & 32,715 & 0.200 \\
\hline 3-Buten-2-ol, 2,3-dimethyl- & 31.600 & TIC & 97,200 & 22,430 & 0.107 \\
\hline Geraniol cis $(Z)-$ & 32.427 & TIC & 847,203 & 40,371 & 0.936 \\
\hline trans Geraniol (E)- & 33.245 & TIC & $6,074,456$ & 249,366 & 6.711 \\
\hline Geranic acid & 37.190 & TIC & 145,179 & 28,938 & 0.160 \\
\hline Isoeugenol & 37.636 & TIC & 251,368 & 51,836 & 0.278 \\
\hline
\end{tabular}


Table 3. The main phytochemical constituents of Ocimum basilicum L. essential oil identified by GC-MS analysis.

\begin{tabular}{|c|c|c|c|c|c|}
\hline Name & R. Time & $\mathbf{m} / \mathbf{z}$ & Area & Height & Concentration \\
\hline alpha Thujene & 6.367 & TIC & 76,945 & 12,186 & 0.086 \\
\hline Beta Myrcene & 10.169 & TIC & 64359 & 8994 & 0.072 \\
\hline Cyclobutane, 1,3-diisopropenyl-, trans & 11.274 & TIC & 75,600 & 11,946 & 0.084 \\
\hline Pentane, 3-bromo- & 11.495 & TIC & 87,739 & 12594 & 0.098 \\
\hline cis Ocimene & 12.703 & TIC & 328,154 & 51,598 & 0.365 \\
\hline Oxalic acid, cyclobutyl, ethyl ester & 13.722 & TIC & 32,818 & 4744 & 0.037 \\
\hline 2,3-Hexanedione & 14.383 & TIC & 27,218 & 4452 & 0.030 \\
\hline 5-Hepten-2-one, 6-methyl- & 14.970 & TIC & 193,362 & 35,549 & 0.215 \\
\hline Linalool oxide & 18.840 & TIC & 142,022 & 13,853 & 0.158 \\
\hline beta Linalool & 20.748 & TIC & $32,664,606$ & $2,147,497$ & 36.375 \\
\hline alpha Bergamotene & 22.058 & TIC & 674,455 & 102,291 & 0.751 \\
\hline beta Caryophyllene & 22.482 & TIC & 502,819 & 75,620 & 0.560 \\
\hline beta Famescene & 23.426 & TIC & 44,046 & 8090 & 0.049 \\
\hline Estragole & 23.735 & TIC & $41,294,691$ & $5,420,144$ & 45.985 \\
\hline cis Citral & 24.005 & TIC & $1,938,577$ & 276,407 & 2.159 \\
\hline .alpha.-Caryophyllene & 24.208 & TIC & 156,947 & 27,279 & 0.175 \\
\hline beta Famescene & 24.208 & TIC & 156,947 & 27,279 & 0.175 \\
\hline 1,6-Octadiene, 2,6-dimethyl- & 24.930 & TIC & 127,610 & 20,567 & 0.142 \\
\hline trans Citral & 25.171 & TIC & $1,594,351$ & 276,329 & 1.775 \\
\hline 1,6,10-Dodecatriene, 7,11 dimethyl-3 methyle- & 25.389 & TIC & 36646 & 9762 & 0.041 \\
\hline Geranyl isobutyrate & 25.680 & TIC & 61,547 & 11,094 & 0.069 \\
\hline cis alpha Bisabolene & 26.434 & TIC & $1,926,980$ & 319,323 & 2.146 \\
\hline 3-Methylbenzothiophene & 27.345 & TIC & 14,437 & 4604 & 0.016 \\
\hline Cinnamaldehyde & 31.855 & TIC & 63,862 & 12,081 & 0.071 \\
\hline 1-Heptyn-4-ol & 32.343 & TIC & 50,217 & 5030 & 0.056 \\
\hline Isoeugenol & 33.943 & TIC & 55,670 & 5993 & 0.062 \\
\hline Thymol & 34.423 & TIC & $6,085,833$ & 489,592 & 6.777 \\
\hline Carvacrol & 35.287 & TIC & $1,083,683$ & 96,648 & 1.207 \\
\hline Benzofuran & 39.662 & TIC & 18,232 & 3811 & 0.020 \\
\hline Butane, 1-methoxy-3-methyl- & 39.893 & TIC & 19,062 & 3160 & 0.021 \\
\hline 3-Methoxycinnamaldehyde & 41.306 & TIC & 200,139 & 41,695 & 0.223 \\
\hline
\end{tabular}

\subsection{Cell Viability Assessment}

In order to analyze the capacity of EOs to inhibit cell proliferation, the 3-(4,5)-dimethylthiazol-2-yl-2,5-diphenyltetrazolium bromide (MTT) assay was performed. Five concentrations $(5,10,25,50,75 \mu \mathrm{g} / \mathrm{mL})$ of each oil considered were tested on HT-29 and Caco-2 human adenocarcinoma cell lines for $48 \mathrm{~h}$. In all cases, the viability percentages varied in a concentration-dependent manner, EOs displaying an anti-cancer effect only at high concentrations. Hr_EO (Figure 1) exerts a similar cytotoxic activity in both cell lines, the most significant effect being registered at $75 \mu \mathrm{g} / \mathrm{mL}$ when the viability percentages reached the values of $87.83 \%$ (Caco-2) and $86.91 \%$ (HT-29). Cc_EO decreased the viability of Caco-2 cells only at $75 \mu \mathrm{g} / \mathrm{mL}$ (62.69\%) (Figure 2A), while the viability of HT-29 cells declined after the $48 \mathrm{~h}$ treatment with Cc_EO $50 \mu \mathrm{g} / \mathrm{mL}(64.09 \%)$ and $75 \mu \mathrm{g} / \mathrm{mL}$ (46.58\%) (Figure 2B). Similar to Hr_EO, Ob_EO significantly reduced the cell viability at the highest concentration tested $(75 \mu \mathrm{g} / \mathrm{mL}-53.36 \%$ in Caco-2 cells (Figure $3 \mathrm{~A}$ ) and $80.67 \%$ in HT-29 cells (Figure 3B)), while at lower concentrations a stimulatory effect was noticed (all viability percentages were over $100 \%$ ). 
A)

Caco-2 - colorectal adenocarcinoma

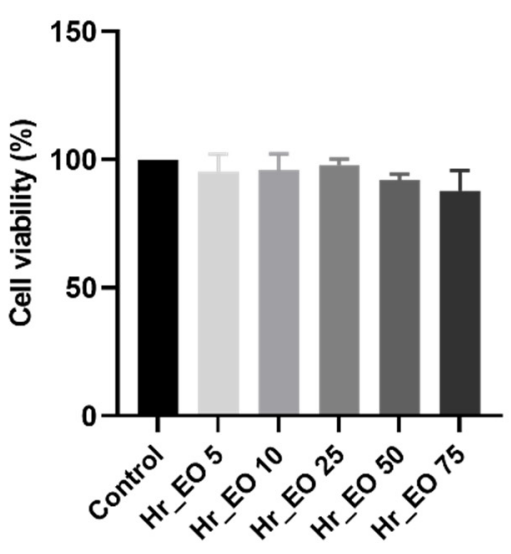

Concentration $(\mu \mathrm{g} / \mathrm{ml})$
B)

HT-29 - colorectal adenocarcinoma

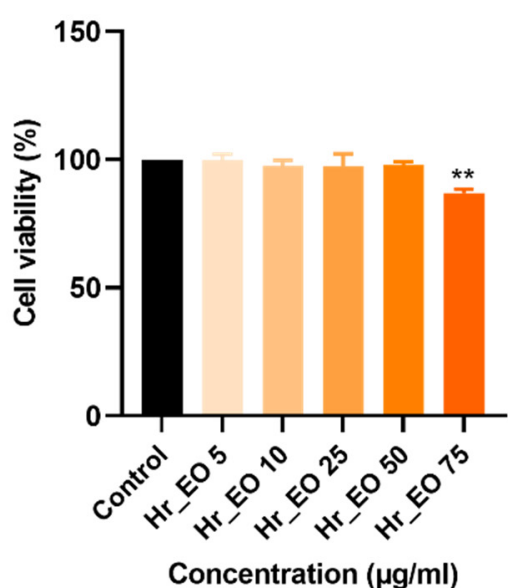

Figure 1. In vitro assessment of the effect $\mathrm{Hr} \_\mathrm{EO}(5,10,25,50$, and $75 \mu \mathrm{g} / \mathrm{mL})$ exerts on the viability of (A) Caco-2 and (B) HT-29 colorectal adenocarcinoma cells after $48 \mathrm{~h}$ of treatment by applying the MTT assay. The data are presented as viability percentages (\%) normalized to control (untreated cells) and expressed as mean values $\pm \mathrm{SD}$ of three independent experiments performed in triplicate. The statistical differences between the control and the treated group were identified by applying the one-way ANOVA analysis followed by the Dunett's multiple comparisons post-test $\left({ }^{* *} p<0.01\right)$.

A)

Caco-2 colorectal adenocarcinoma

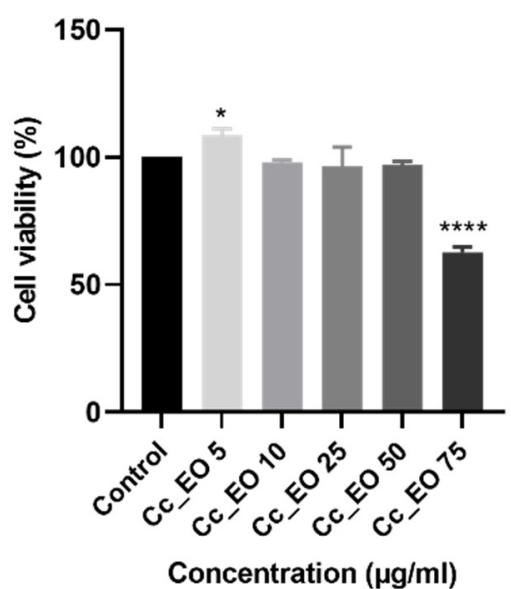

B)

HT-29 - colorectal adenocarcinoma

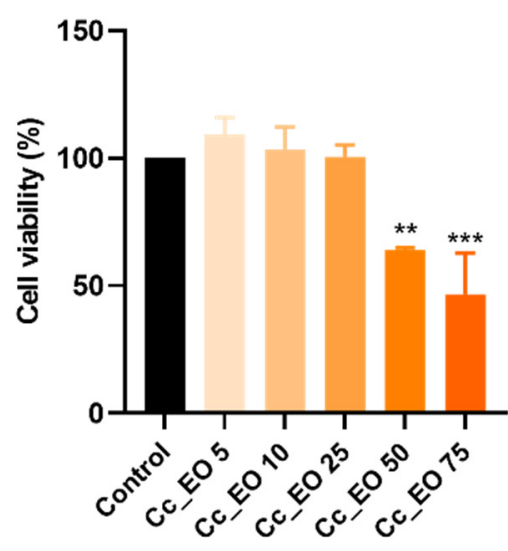

Concentration $(\mu \mathrm{g} / \mathrm{ml})$

Figure 2. In vitro assessment of the effect CC_EO $(5,10,25,50$, and $75 \mu \mathrm{g} / \mathrm{mL})$ exerts on the viability of (A) Caco-2 and (B) HT-29 colorectal adenocarcinoma cells after $48 \mathrm{~h}$ of treatment by applying the MTT assay. The data are presented as viability percentages (\%) normalized to control (untreated cells) and expressed as mean values \pm SD of three independent experiments performed in triplicate. The statistical differences between the control and the treated group were identified by applying the one-way ANOVA analysis followed by the Dunett's multiple comparisons post-test $\left(^{*} p<0.1 ;{ }^{* *} p<0.01\right.$; *** $\left.p<0.001 ;{ }^{* * * *} p<0.0001\right)$. 
A)

Caco-2 colorectal adenocarcinoma

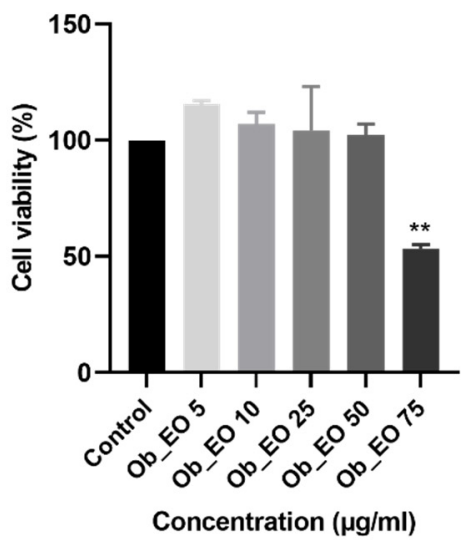

B)

HT-29 - colorectal adenocarcinoma

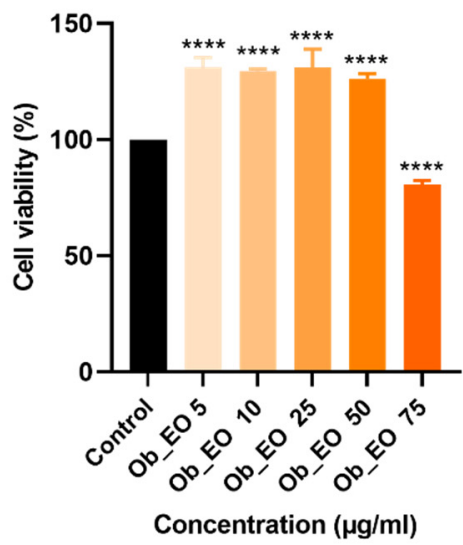

Figure 3. In vitro assessment of the effect $\mathrm{Ob} \_\mathrm{EO}(5,10,25,50$, and $75 \mu \mathrm{g} / \mathrm{mL})$ exerts on the viability of (A) Caco-2 and (B) HT-29 colorectal adenocarcinoma cells after $48 \mathrm{~h}$ of treatment by applying the MTT assay. The data are presented as viability percentages (\%) normalized to control (untreated cells) and expressed as mean values \pm SD of three independent experiments performed in triplicate. The statistical differences between the control and the treated group were identified by applying the one-way ANOVA analysis followed by the Dunett's multiple comparisons post-test $\left({ }^{* *} p<0.01 ;{ }^{* * * *} p<0.0001\right)$.

\subsection{Cell Morphology and Confluence}

As a component of the anti-cancer profile of EOs, a microscopic examination of the Caco- 2 cells (Figure 4 ) was performed at the end of the $48 \mathrm{~h}$ treatment. The lowest $(5 \mu \mathrm{g} / \mathrm{mL}$ ) and the highest $(75 \mu \mathrm{g} / \mathrm{mL})$ concentrations were selected for this experiment. All three EOs (Hr_EO, Cc_EO, Ob_EO) induced a significant loss in the cells' confluence and adherence at $75 \mu \mathrm{g} / \mathrm{mL}$, while at $5 \mu \mathrm{g} / \mathrm{mL}$ no changes can be noted when compared to control.

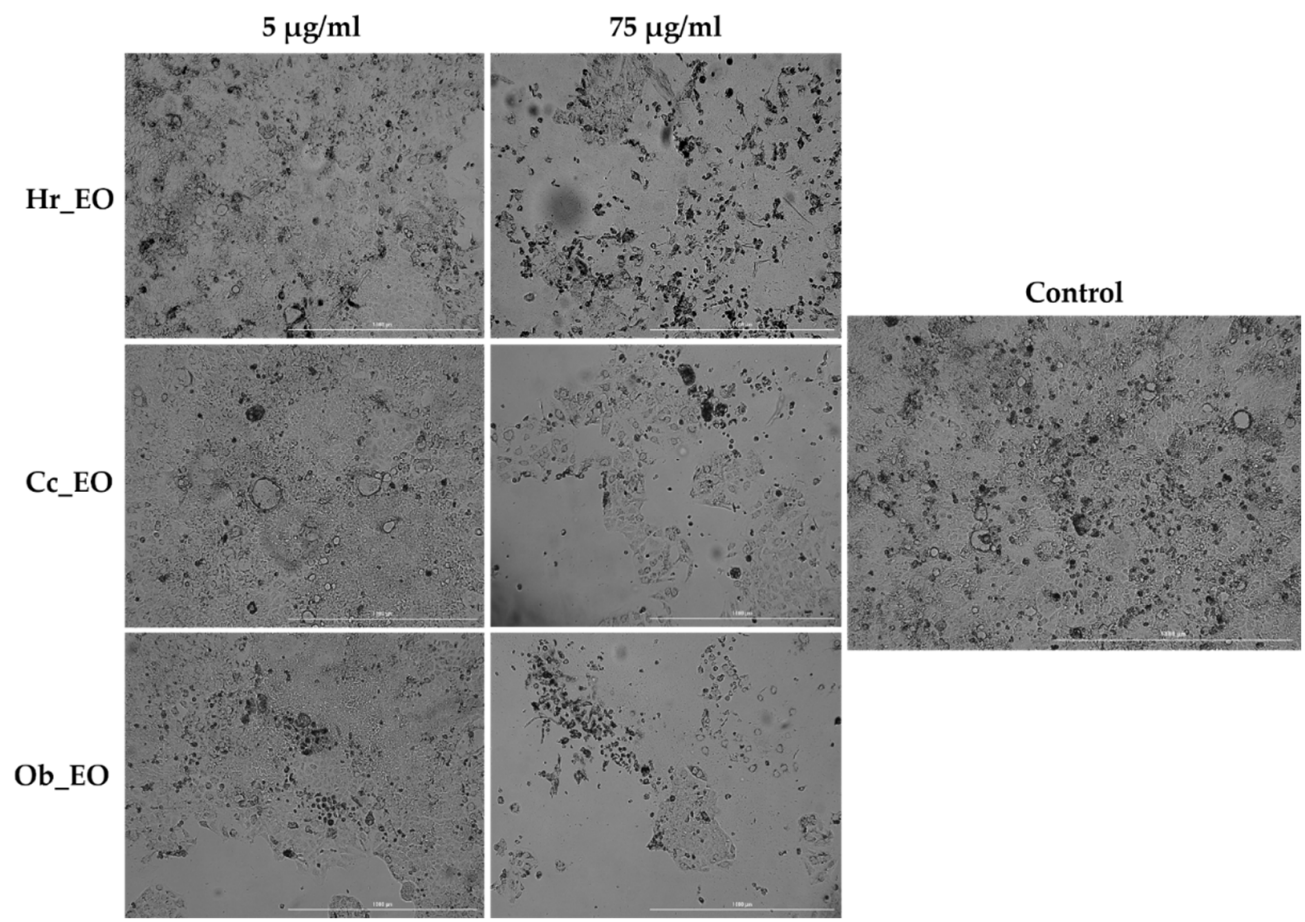

Figure 4. Pictures illustrating the morphological aspect and confluence of Caco-2 colorectal adenocarcinoma cells following the $48 \mathrm{~h}$ treatment with $\mathrm{Hr} \_$EO, Cc_EO, and Ob_EO (5 and $\left.75 \mu \mathrm{g} / \mathrm{mL}\right)$. The scale bars represent $1000 \mu \mathrm{m}$. 


\subsection{Nuclear Morphology Evaluation}

Considering the viability results, the next step was a preliminary experiment to identify whether cell death occurred by apoptosis or necrosis. Hence, HT-29 and Caco-2 cells were stimulated for $48 \mathrm{~h}$ with two different concentrations ( 5 and $75 \mu \mathrm{g} / \mathrm{mL}$ ) of Hr_EO, Cc_EO, and Ob_EO, the cell nuclei were counterstained using the Hoechst 33342 reagent, and the results were compared with control (unstimulated) cells. In the case of Caco-2 (Figure 5) and HT-29 (Figure 6) control cells, the nuclei have a round and regular shape, evenly stained, without signs of fragmentation. However, following the $48 \mathrm{~h}$ treatment with EOs, several changes in the aspect of the cellular nuclei were observed only at the highest concentration tested-75 $\mu \mathrm{g} / \mathrm{mL}$. Hr_EO induced nuclear fragmentation in Caco-2 cells, and membrane blebbing in HT-29 cells. Cc_EO induced visible dysmorphology only in HT29 cells (nuclear condensation and fragmentation). In Caco-2 cells, Ob_EO caused nuclear fragmentation, chromatin condensation, and massive nuclear growth, while in HT-29 cells chromatin condensation and nuclei fragmentation were noticed. The results regarding the apoptotic-like features, are indicated by arrows. The Hoechst 33342 results are expressed as apoptotic index (AI) as well. All EOs induced an increase in the AI percentage as compared to control where no signs of apoptosis were detected. The most significant results were obtained in HT-29 cells at the concentration of $75 \mu \mathrm{g} / \mathrm{mL}$ with AI values of $94.27 \%$ (Hr_EO), $57.85 \%$ (Cc_EO), and $46.66 \%$ (Ob_EO). In Caco-2 cells, the registered AI percentages were $13.83 \%$ (Hr_EO), $3.93 \%$ (Cc_EO), $25.03 \%$ (Ob_EO) at $75 \mu \mathrm{g} / \mathrm{mL}$.

A)

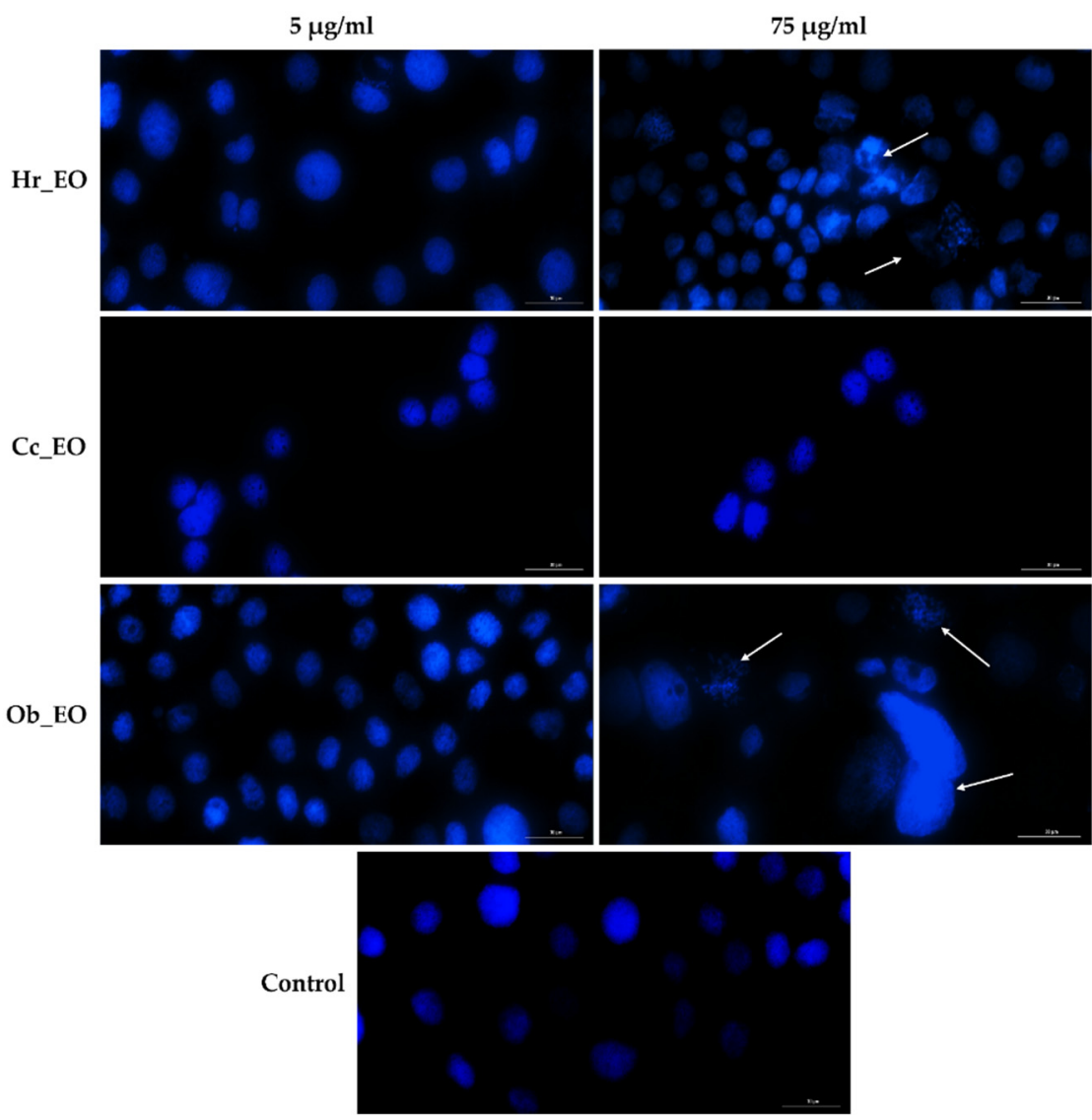

B)

Caco-2 - colorectal carcinoma

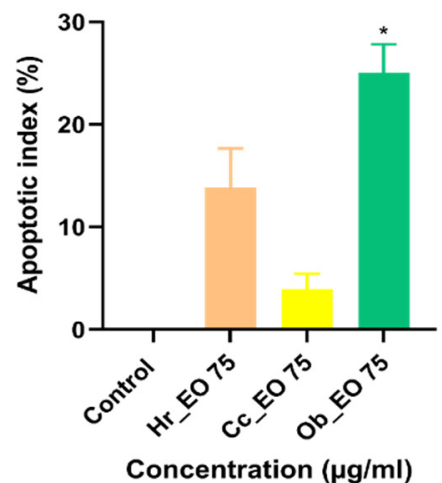

Figure 5. (A) Images of the cellular nuclei stained using Hoechst 33342 reagent in Caco-2 CRC cells following the $48 \mathrm{~h}$ treatment with Hr_EO, Cc_EO, and Ob_EO $(5$ and $75 \mu \mathrm{g} / \mathrm{mL})$ and $(\mathbf{B})$ calculated apoptotic index (AI) percentages for the highest concentration tested $(75 \mu \mathrm{g} / \mathrm{mL})$. The arrows indicate nuclei expressing apoptotic features. The scale bars represent $30 \mu \mathrm{m}$. Data are presented as an apoptotic index (\%) normalized to control and expressed as mean values \pm SD of three independent experiments. The statistical differences between control and the treated group were verified by applying the one-way ANOVA analysis followed by Dunnett's multiple comparisons post-test $\left.{ }^{*} p<0.1\right)$. 
A)

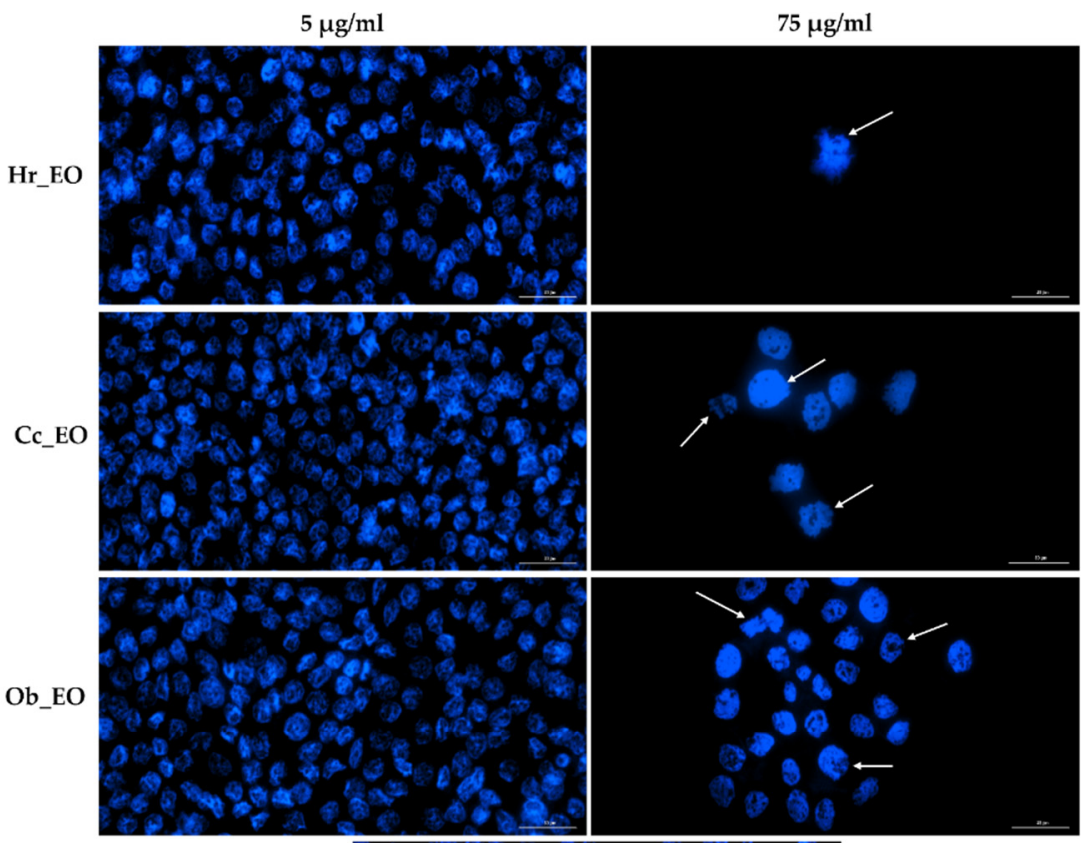

B)

HT-29 - colorectal carcinoma
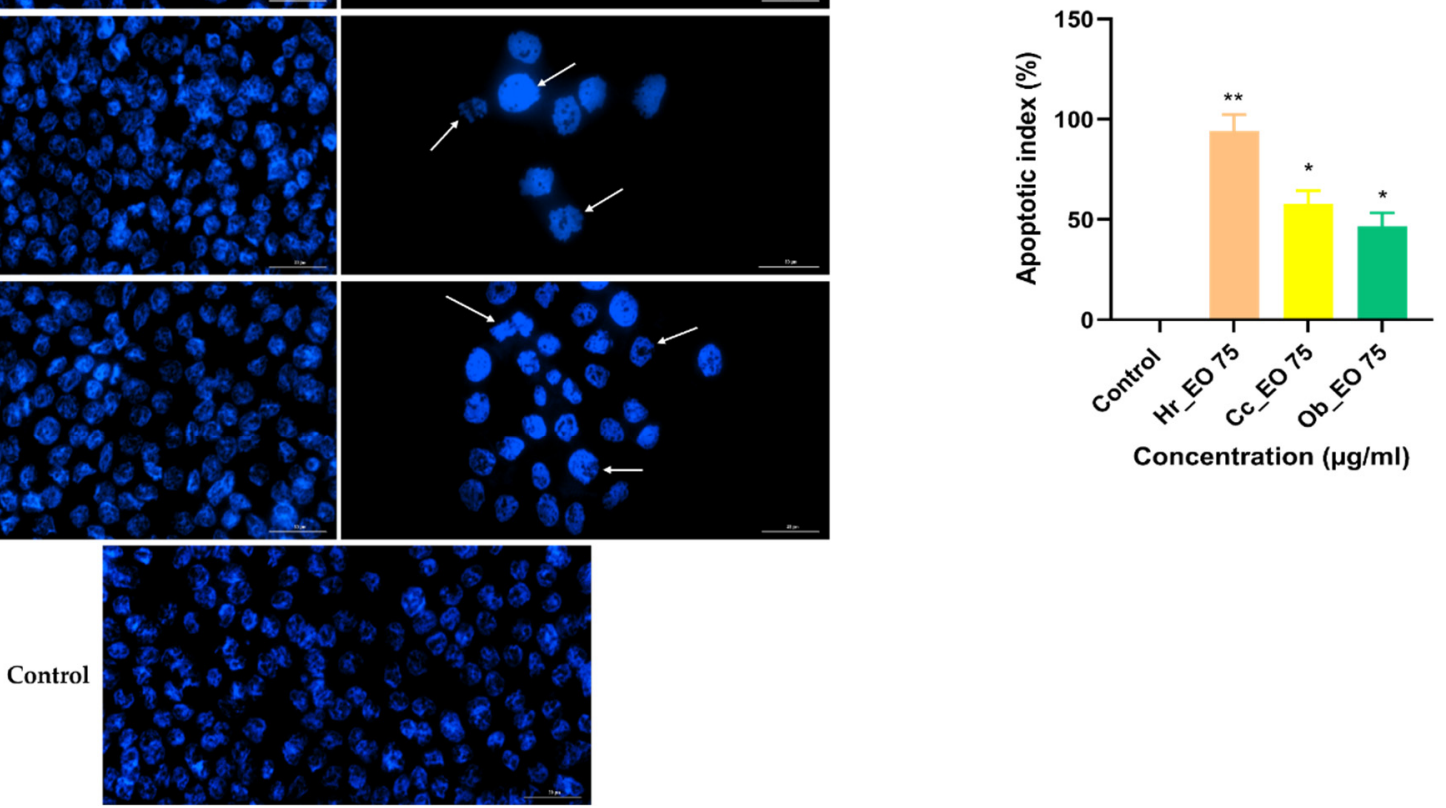

Figure 6. (A) Images of the cellular nuclei stained using Hoechst 33342 reagent in HT-29 CRC cells following the $48 \mathrm{~h}$ treatment with Hr_EO, Cc_EO, and Ob_EO (5 and $75 \mu \mathrm{g} / \mathrm{mL})$ and (B) calculated apoptotic index (AI) percentages for the highest concentration tested $(75 \mu \mathrm{g} / \mathrm{mL})$. The arrows indicate nuclei expressing apoptotic features. The scale bars represent $30 \mu \mathrm{m}$. Data are presented as an apoptotic index (\%) normalized to control and expressed as mean values \pm SD of three independent experiments. The statistical differences between control and the treated group were verified by applying the one-way ANOVA analysis followed by Dunnett's multiple comparisons post-test $\left({ }^{*} p<0.1 ;{ }^{* *} p<0.01\right)$.

\subsection{Wound Healing Assay}

In order to evaluate the impact of EOs on the migration of Caco-2 and HT-29 cells, a wound healing assay was performed. The cells were treated with two concentrations (5 and $50 \mu \mathrm{g} / \mathrm{mL}$ ) of each oil for $24 \mathrm{~h}$. The results were highly depended on the tested oil, cell line, and concentration (Figure 7). Significant inhibition in the cells' migration was noticed following their treatment with $\mathrm{Hr} \_$EO $50 \mu \mathrm{g} / \mathrm{mL}$ with wound healing rates of $27.61 \%$ (Caco-2) and $11.78 \%$ (HT-29), which are lower when compared to control (40.73\%-Caco-2; $25.20 \%$ - HT-29). The same tendency was observed in the case of Cc_EO, but at $50 \mu \mathrm{g} / \mathrm{mL}$ it presented a much better capacity for migratory inhibition, especially on HT-29 cells, with a wound healing rate (WHR) of $3.40 \%$. Ob_EO was generally associated with a significant increase in the cells' migration rate. 
A)

Caco-2 - colorectal adenocarcinoma

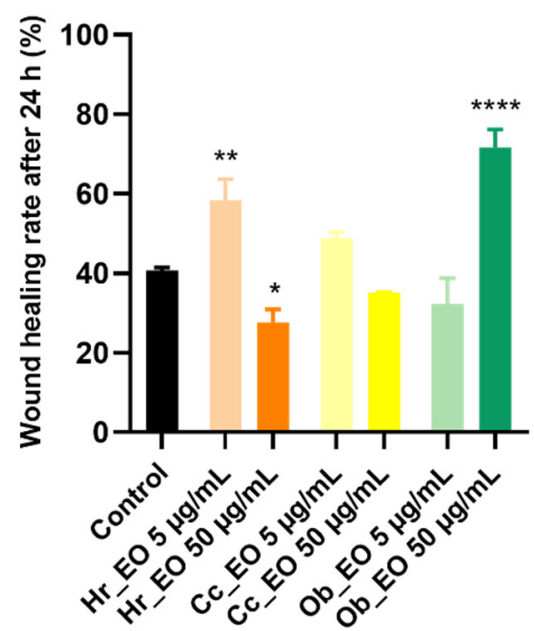

B)

HT-29 - colorectal adenocarcinoma

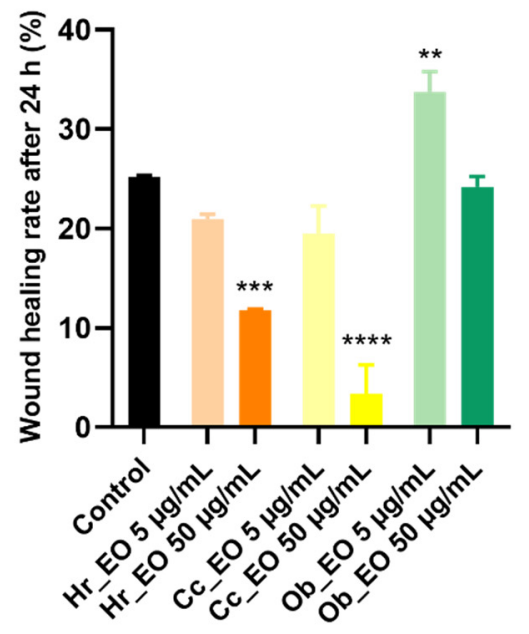

Figure 7. Graphic representation of the migratory capacity of Caco-2 (A) and HT-29 (B) colorectal adenocarcinoma cells following the treatment with Hr_EO, CC_EO, and Ob_EO 5 and $50 \mu \mathrm{g} / \mathrm{mL}$ for $24 \mathrm{~h}$. The bar graphs are presented as percentage of wound closure after $24 \mathrm{~h}$ compared to the initial surface. The data are expressed as mean values \pm SD of three independent experiments performed in triplicate. To identify the statistical differences between the control and the treated group, the one-way ANOVA analysis was conducted followed by the Dunett's multiple comparisons post-test $\left({ }^{*} p<0.1\right.$; $\left.{ }^{* *} p<0.001 ;{ }^{* * *} p<0.0001 ;{ }^{* * * *} p<0.0001\right)$.

\subsection{HET-CAM Assay}

To determine the irritant potential of the three volatile oils (Hr_EO, Cc_EO, and Ob_EO), the HET-CAM method was applied considering that the safety profile is important for further in vivo evaluations. During the experiments, important data regarding the toxic potential of substances are provided both by calculating the irritation score and by analyzing the impact on vessels. To have a clear picture of the effects exerted by volatile oils, distilled water was used as negative control, while sodium dodecyl sulfate (SDS) $1 \%$ was a positive control. Thus, Table 4 presents the values of the irritation score obtained for the three samples, but also for the controls. In the case of positive control, SDS, the highest value of the irritation score of about 20 was obtained. At the opposite pole is distilled water, with a value of the irritation score being 0.1 . Between these values are the three tested samples, the value of the irritation score in this case being closer to that of water, which suggests that all the essential oils tested were free of irritating effects on the vascular plexus. However, in Figure 8, the images made at the chorioallantoic membrane before and after the application of the substances can be observed. In the case of SDS, in the first minute after its application, strong irritating effects, such as lysis, coagulation, and vascular hemorrhage were registered at the level of the chorioallantoic membrane. In the case of volatile oils, they did not cause major changes in the vascular plexus, the only effect recorded being a slight intravascular coagulation, recorded at the end of the five minutes. However, the viability of chicken embryos was good, and they survived even after $24 \mathrm{~h}$ of application of the samples (Figure 8). 
Table 4. Irritation score values for positive control (sodium dodecyl sulfate 1\%), negative control (distilled water), H. rhamnoides L., C. citratus (D.C.) Stapf and O. basilicum L. essential oils (Hr_EO, Cc_EO, and Ob_EO).

\begin{tabular}{cccccc}
\hline & SDS $\mathbf{1 \%}$ & $\mathbf{H}_{\mathbf{2}} \mathbf{O}$ & Hr_EO & Cc_EO & Ob_EO \\
\hline IS & 19.68 & 0.10 & 1.12 & 0.99 & 1.26 \\
tH & $15 \mathrm{~s}$ & 300 & 300 & 300 & 300 \\
tL & $18 \mathrm{~s}$ & 300 & 273 & 295 & 268 \\
tC & $24 \mathrm{~s}$ & 299 & 286 & 273 & 285 \\
\hline
\end{tabular}

SDS-sodium dodecyl sulfate; IS-irritation score; tH-time of hemorrhage; $\mathrm{tL}$-time of lysis; $\mathrm{tC}$-time of coagulation.
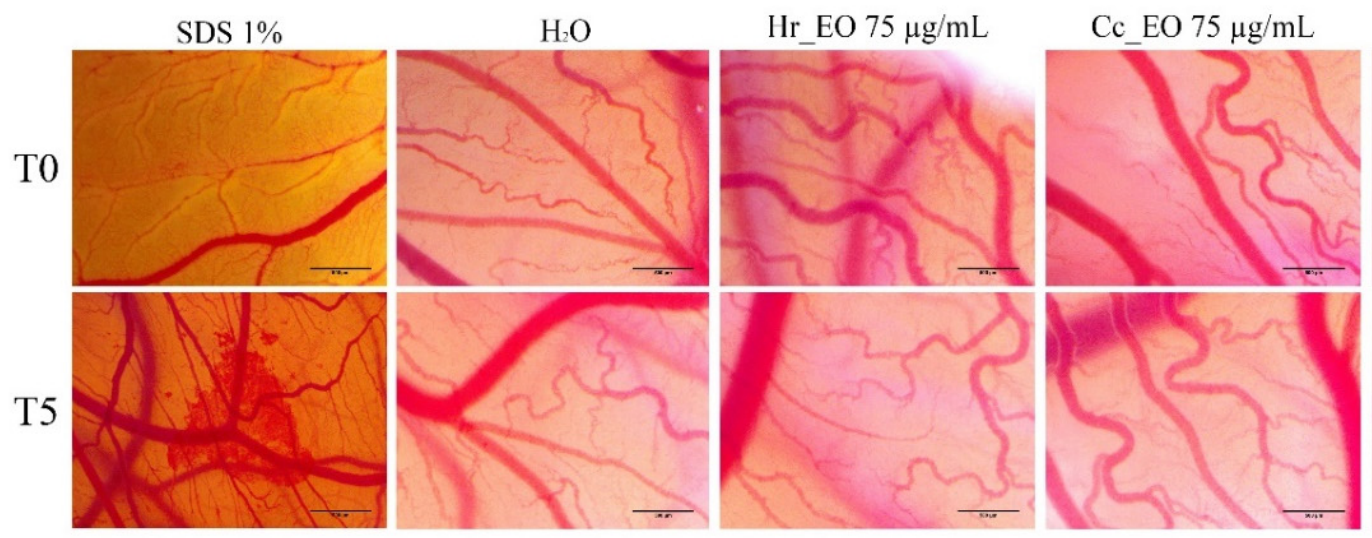

Ob_EO $75 \mu \mathrm{g} / \mathrm{mL}$

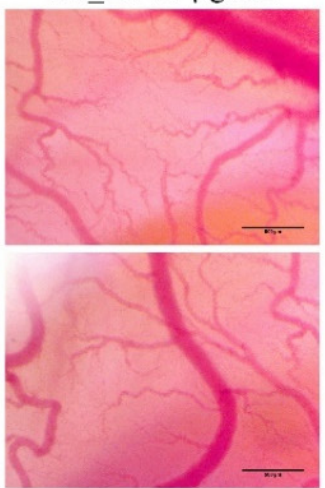

Figure 8. Stereomicroscope images of the CAMs inoculated with negative control (distilled water- $\mathrm{H}_{2} \mathrm{O}$ ), positive control (sodium dodecyl sulfate-SDS), and essential oil test samples (Hr_EO, Cc_EO, and Ob_EO).

\section{Discussion}

Colorectal cancer remains one of the leading causes of death worldwide, with an incidence which is alarmingly growing, and with limited therapy options in advanced stages. Considering the multitude of natural sources available for compound isolation and their ability to prevent tumor occurrence, as well as target tumor cells after disease onset, plant-derived products have gained substantial interest in the area of cancer research [20]. To date, several publications direct the use of phytocompounds (e.g., flavonoids, stilbenes, terpenes) and plant extracts (e.g., S. libanotica, H. rhamnodies, M. fragrance, C. sinensis, C.n citratus, M. piperita, O. basilicum L.) toward CRC chemotherapy $[15,21,22]$.

The purpose of the present study was to evaluate the quality of three commercial essential oils (Hr_EO, Ob_EO, and CC_EO) in terms of phytochemical composition and in vitro anti-cancer effect on two CRC cell lines-Caco-2 and HT-29-which are isolated from human colon adenocarcinomas, and largely used as in vitro models in CRC studies. The Caco-2 cell line is capable to form polarized monolayers in culture and differentiates into cells with high homology to enterocytes in the intestinal epithelium. HT-29 cells are essentially undifferentiated in culture, but they contain a small proportion (i.e., $<5 \%$ ) of mucus-secreting cells and columnar absorptive cells, a property which offers them heterogeneity [23]. Our findings in this direction indicate the following aspects: (i) the tested commercial EOs are rich in natural compounds, among which estragole (in Hr_EO and Ob_EO), alpha- and beta-citral (in C__EO) are present in the highest amount, and (ii) after $48 \mathrm{~h}$ of treatment Hr_EO, Ob_EO, and Cc_EO induce cytotoxic effects in CRC cells, which are highly dependent on the tested EO. Considering the possible toxicity of EOs, their effect on the morphology of healthy human keratinocytes (HaCaT cell line) was first evaluated. The preliminary results indicated a weak toxic effect at the highest concentration tested $(75 \mu \mathrm{g} / \mathrm{mL})$, reflected by a slight reduction in the cells' confluence when compared to Caco-2 CRC cells. 
In the case of commercial Hr_EO, the GC-MS analysis revealed the presence of $13 \mathrm{com}$ pounds (Table 1), among which estragole represented $63.1 \%$ from the total oil composition and could be associated with the biological effects exerted by Hr_EO. Estragole is a representative of the alkenylbenzenes class [24], exerting cytoprotective, antioxidant, and anti-inflammatory properties on gastric cells [25], and pro-apoptotic effects on HepG2 hepatocarcinoma cells [24]. In the realm of colorectal cancer, this phytocompound has not been studied so far. Regarding the in vitro anti-CRC activity of Hr_EO, the most significant effect has been noticed at the highest concentration tested $(75 \mu \mathrm{g} / \mathrm{mL})$, when the cellular viability (Caco-2-87.83\%; HT-29-86.91\%) and the confluence of Caco-2 cells were significantly reduced (Figures 1 and 4). In addition, at this concentration, apoptotic-like nuclear features (fragmentation, membrane blebbing) and an increase in the AI percentages (to $13.83 \%$ in Caco-2 cells, and $94.27 \%$ in HT-29 cells) when compared to control were detected (Figures 5 and 6). At a lower concentration $(50 \mu \mathrm{g} / \mathrm{mL}), \mathrm{Hr} \_$EO inhibited the migration of Caco-2 $(\mathrm{WHR}=27.61 \%)$ and HT-29 $(\mathrm{WHR}=11.78 \%)$ cells when compared to control (WHR $=40.73 \%$-Caco-2; WHR $=25.20 \%-$ HT-29) -Figure 7. In a previous study, Olsson et al. showed that Sea buckthorn extract exerted a high inhibitory effect on the proliferation of HT-29 cells at concentrations of $0.25 \%$ and $0.5 \%$, correlating this observation with the synergistic action between carotenoids, vitamin $C$, and anthocyanins present in the extract $[10,26]$.

Regarding Cc_EO composition (Table 2), the primary phytochemical constituents are alpha- and beta-citral (37.23\% and $28.91 \%$, respectively). Citral is a natural compound possessing well-defined anti-tumor properties, especially in the case of breast carcinoma, stomach, and prostate cancers by inducing apoptosis and inhibiting metastasis [27-30]. Cc_EO exerted a strong in vitro anti-CRC effect at $75 \mu \mathrm{g} / \mathrm{mL}$, in terms of cellular viability which decreased to $62.69 \%$ in Caco- 2 cells and $46.58 \%$ in HT-29 cells following the $48 \mathrm{~h}$ treatment (Figure 2). These results were accompanied by a significant loss in the Caco-2 cells' confluence (Figure 7), visible nuclear dysmorphology (condensation and fragmentation), and elevated AI (57.85\%) in HT-29 cells at $75 \mu \mathrm{g} / \mathrm{mL}$ (Figure 6). When compared to untreated cells $($ WHR $=25.20 \%$ ), CC_EO manifested a strong inhibitory effect on the viability of HT-29 cells at low $(5 \mu \mathrm{g} / \mathrm{mL})$ and high $(50 \mu \mathrm{g} / \mathrm{mL})$ concentrations with WHR values of $19.49 \%$ and $3.40 \%$, respectively. Considering the migration of Caco- 2 cells, the effect induced by Cc_EO was statistically insignificant (Figure 7). In a recent study, Ruvinov and colleagues analyzed the anticarcinogenic potency of $C$. citratus ethanolic extract on aggressive CRC cell lines (HT-29 and HCT-116), noting its ability to induce apoptosis, as well as enhance the efficacy of FOLFOX CRC-specific treatment while reducing the adverse events [31].

In Ob_EO, a total of 31 phytocompounds were detected by GC-MS, with estragole $(45.9 \%)$ being the most prominent (Table 3$)$. This EO potently reduced the cell viability at the highest concentration tested $(75 \mu \mathrm{g} / \mathrm{mL}-53.36 \%$ in Caco-2 cells and $80.67 \%$ in HT-29 cells), while at lower concentrations all viability percentages were over 100\%. In addition, Ob_EO affected the confluence and adherence of Caco-2 cells at $75 \mu \mathrm{g} / \mathrm{mL}$ (Figure 4), caused nuclear fragmentation and chromatin condensation in both cell lines (Figures 5 and 6), and elevated the AI to $25.03 \%$ (Caco-2) and $46.66 \%$ (HT-29). Ob_EO significantly increased the cells' migration rate at 5 (HT-29) and $50 \mu \mathrm{g} / \mathrm{mL}$ (Caco-2) (Figure 7). Fitsiou et al. observed a similar anti-proliferative effect induced by O. basilicum EO in Caco-2 CRC cells $\left(\mathrm{EC}_{50}=0.071 \pm 0.0032 \mathrm{mg} / \mathrm{mL}\right)$ [32].

With a design to determine the potential irritating effect of the three volatile oils evaluated in the present study, the HET-CAM method was chosen, which uses a biological model including the chorioallantoic membrane of the chicken egg. The results obtained showed that none of the three oils exert an irritating effect on the vascular plexus. As proof of the safety profile, the values obtained for the irritation score of the volatile oils were around one. These results are useful for possible future in vivo tests because volatile oils have a low density and a high lipophilia which favor skin penetration [33]. In regards to H. rhamoides, an extract obtained from the leaves of this plant has been previously tested 
on the chorioallantoic membrane, being noted as having an antiangiogenic effect [34]. C. citratus essential oil was evaluated for the local irritant effect using a murine model, with the observation that the essential oil did not exert any toxic effect on the skin [35], data that agree with the ones recorded in the current study. As far as we know, these two volatile oils (H. rhamoides and C. citratus) have not been tested for the irritating effect by employing the HET-CAM method. On the other hand, in a study on the irritating effect of two hydroalcoholic extracts of $O$. basilicum, Faur et al., assessed the toxic potential at the chorioallantoic membrane, concluding that $O$. basilicum has a good biocompatibility and tolerance at this level [36].

In order to analyze the in vivo effect of the essential oils, different studies were performed. In the case of Hr_EO, anti-tumor properties were reported, especially in the case of cervical cancer, melanoma, and sarcoma [37], and Upadhyay et al. highlighted no adverse effects in subjects after the administration of sea buckthorn oil [38]. In addition, Kumar et al. indicated the beneficial effect exerted by $H$. ramnodies oil on cancer treatment and cancer patients' good health by counteracting many side effects induced by chemo- or radiotherapy, restoring kidney and liver functions, and increasing appetite [39].

Regarding medicinal usefulness of C__EO, Bidinotto and colleagues evaluated the beneficial effects of the essential oil as oral treatment on cell proliferation and apoptosis events, and on early development of hyperplastic lesions in the colon, mammary gland, and urinary bladder induced by N-methyl-N-nitrosourea in female BALB/c mice. Results showed that $C$. citratus oral treatment significantly changed the indexes of apoptosis and /or cellular proliferation for the tissues analyzed, especially on mammary tissue [40]. The effect may be due to beta-citral, the major compound found in the sample. Nguyen et al. concluded that $C$. citratus sample was able to significantly reduce the tumor burden in prostate cancer xenograft models when administered orally, while also being well tolerated [41]. Ob_EO, due to a high level of estragole, is capable of increasing glutathioneS-transferase activity by more than $78 \%$ in the liver, stomach, and esophagus-to a strength high enough to be considered as protective agents against carcinogenesis [42]. The antiinflammatory action was confirmed by Rodrigues et al. using acute and chronic in vivo tests as paw edema, peritonitis, and vascular permeability and granulomatous inflammation model. The anti-inflammatory mechanism of action was analyzed by the participation of histamine and arachidonic acid pathways [43].

\section{Materials and Methods}

\subsection{Reagents}

The essential oils (EOs)—Hr_EO, Cc_EO, and Ob_EO, were purchased from SC Hofigal Export Import SA, BIONOVATIV SRL, and Adams Vision SRL, respectively (Bucharest, Romania). Phosphate saline buffer (PBS), trypsin-EDTA solution, dimethyl sulfoxide (DMSO), fetal bovine serum (FBS), penicillin/streptomycin, and MTT reagent were purchased from Sigma Aldrich, Merck KgaA (Darmstadt, Germany). The cell culture media, Eagle's Minimum Essential Medium (EMEM-ATCC ${ }^{\circledR}$ 30-2003 ${ }^{\mathrm{TM}}$ ), and McCoy's 5A Medium $\left(\right.$ ATCC $^{\circledR} 30-2007^{\mathrm{TM}}$ ) were purchased from ATCC (American Type Cell Collection, Lomianki, Poland). N-hexane was purchased from Merck (Darmstadt, Germany). All the reagents were of analytical standard purity and were applied according to the manufacturers' recommendations.

\subsection{Gas Chromatography-Mass Spectrometry (GC-MS) Analysis}

Before GC-MS analysis, the oils were diluted 1:10 $(v / v)$ with n-hexane (Merck, Darmstadt, Germany, CAS-No:110-54-3). EOs' chemical characterization was accomplished using the gas-chromatograph installation with mass spectrometer (GS/MS) QP 2010Plus (Shimadzu, Kyoto, Japan) adapted with AT WAX $30 \mathrm{~m} \times 0.32 \mathrm{~mm} \times 1 \mu \mathrm{m}$ capillary column. Helium was used as a delivery gas at a flow rate of $1 \mathrm{~mL} / \mathrm{min}$. The compounds were submitted to the program: $40^{\circ} \mathrm{C}$ for $1 \mathrm{~min}$, a rate of $5{ }^{\circ} \mathrm{C} / \mathrm{min}$ to $210^{\circ} \mathrm{C}$ for $5 \mathrm{~min}$. Injector and ion source temperatures were $250{ }^{\circ} \mathrm{C}$ and $220^{\circ} \mathrm{C}$, jointly. An injection volume of $1 \mu \mathrm{L}$ 
was used at a split ratio of 1:50. The NIST 02 and Wiley 275 libraries spectra databases were utilized to identify the volatile compounds. The linear retention indices (LRI) were determined in relation to a homologous series of n-alkanes (C8-C24) according to Van den Dool and Kratz formula [44].

\subsection{Cell Culture}

The present study was conducted using two human colorectal adenocarcinoma cell

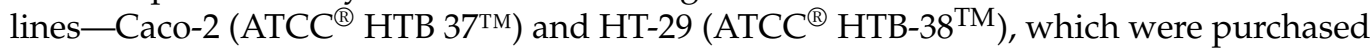
from ATCC (American Type Cell Collection) as frozen vials. Caco-2 cells were cultured in the EMEM Medium supplemented with 20\% FCS, while HT-29 cells were cultured in their specific McCoy's 5A Medium supplemented with 10\% FCS, as presented in literature [45]. Both media contained $1 \%$ antibiotic mixture $(100 \mathrm{U} / \mathrm{mL}$ penicillin/ $100 \mu \mathrm{g} / \mathrm{mL}$ streptomycin) to prevent microbial contamination. The cells were grown under standard conditions: $5 \% \mathrm{CO}_{2}$ and a temperature of $37^{\circ} \mathrm{C}$ in a humidified incubator.

\subsection{Viability Assay}

The cell viability was assessed by applying the MTT technique. Briefly, Caco-2 and HT-29 cells were cultured in 96-well plates $\left(10^{4}\right.$ cells $/ 200 \mu \mathrm{L} /$ well $)$ and treated with different concentration of Eos diluted in DMSO $(5,10,25,50,75 \mu \mathrm{g} / \mathrm{mL})$, followed by $48 \mathrm{~h}$ of incubation. Following the treatment period with different concentration of EOs, $10 \mu \mathrm{L} /$ well of 3-(4,5-dimethylthiazol-2-yl)-2,5-diphenyltetrazolium bromide (MTT) solution $(5 \mathrm{mg} / \mathrm{mL})$ was added and the plate was incubated for $3 \mathrm{~h}$, the formazan crystals formed were dissolved ( $30 \mathrm{~min}$ in the dark) in $100 \mu \mathrm{L}$ of solubilization buffer provided by the manufacturer. Finally, the reduced MTT was spectrophotometrically measured at $570 \mathrm{~nm}$, using the Cytation 5 (BioTek Instruments Inc., Winooski, VT, USA) microplate reader. All experiments were performed in triplicate.

\subsection{Cell Morphology and Confluence Evaluation}

To assess the changes induced by commercial oils in terms of morphology and confluence, the Caco- 2 cells were microscopically examined under bright field illumination and pictures were taken at $48 \mathrm{~h}$ post-treatment with EOs solubilized in DMSO, at 5, 10, 25, 50, and $75 \mu \mathrm{g} / \mathrm{mL}$ using Cytation 1 (BioTek Instruments Inc., Winooski, VT, USA). The pictures were processed using the Gen5 Microplate Data Collection and Analysis Software (BioTek Instruments Inc., Winooski, VT, USA).

\subsection{Nuclear Morphology Evaluation}

To determine the type of cell death induced by volatile oils, the Hoechst method was performed. The applied protocol followed the manufacturer's instructions. Briefly, cells were cultured at $1 \times 10^{5}$ /well in 12-well plates. After reaching a confluence of approximately $90 \%$, the cells were treated with three different concentrations of EO: 5 , 25 , and $75 \mu \mathrm{g} / \mathrm{mL}$. After $24 \mathrm{~h}$ of treatment, the medium was removed and $100 \mu \mathrm{L}$ of staining solution was added to each well diluted 1:2000 in PBS. After incubation for $10 \mathrm{~min}$ at room temperature and protected from light, the staining solution was removed and washed three times with PBS. The pictures were taken using Cytation 1 (BioTek Instruments Inc., Winooski, VT, USA) and processed using the Gen5 Microplate Data Collection and Analysis Software (BioTek Instruments Inc., Winooski, VT, USA). The apoptotic index was calculated according to a formula described by $\mathrm{Xu}$ et al. [46] and used in one of our previous publications [47].

\subsection{Wound Healing Assay}

To identify the capacity of $\mathrm{Hr} \_\mathrm{EO}, \mathrm{C} \_$EEO, and $\mathrm{Ob} \_\mathrm{EO}$ to interfere with the migration of HT-29 and Caco-2 cells, a wound healing assay was accomplished, following the protocol described in the literature [48]. Succinctly, $2 \times 10^{5}$ cells/well were cultured in 12-well plates, after an $80-90 \%$ confluence, a vertical line was drawn in the middle of the well 
using a sterile pipette tip. The rest of the detached cells was eliminated by washing with PBS. Then, the cells were stimulated with two different concentrations of each oil (5 and $50 \mu \mathrm{g} / \mathrm{mL}$ ). Photos were taken at the time interval of $0 \mathrm{~h}$ and $24 \mathrm{~h}$ using the Olympus IX73 inverted microscope provided with DP74 camera (Olympus Corporation), and cell migration widths were carried out using cell Sense Dimension software.

The scratch closure migration rate (\%) was calculated using the following formula [48]:

$$
\text { Scratch closure rate }=\frac{\left(A_{t 0}-A_{t}\right)}{A_{t 0}} \times 100
$$

where: $A_{t 0}$-scratch closure at time $0 ; A_{t}$-scratch closure at $24 \mathrm{~h}$.

\subsection{Chorioallantoic Membrane Assay (CAM Assay)}

In this study, the chorioallantoic membrane of the chicken egg was used as a biological model to determine the safety profile and irritant potential of three volatile oils: $\mathrm{Hr} \_\mathrm{EO}$, Cc_EO, and Ob_EO. The eggs were purchased from a local farmer and prepared for study following the steps described below: (i) on the first day of the experiment, the eggs were washed and disinfected, then data were entered on them and placed in the incubator; (ii) on the third day of incubation, perforations were made in the eggshell and a volume of approximately $7 \mathrm{~mL}$ of albumen was extracted in order to allow the detachment of the inner shell membrane of the hen's egg; and (iii) on the fourth day of incubation, a window was cut at the top of the hen's egg, large enough to allow the blood vessels to be seen. Then, the perforation was covered with adhesive tape, and the eggs were placed in the incubator until the day the experiment began.

\subsection{Hen's Egg Chorioallantoic Membrane (HET-CAM) Assay}

The potential irritant effect was determined for the three volatile oils used in the highest concentration $(75 \mu \mathrm{g} / \mathrm{mL})$, previously evaluated in vitro in the cell viability test. For a better quantification of the irritating effect, a negative control represented by water and a positive control represented by sodium dodecyl sulfate (SDS) in a concentration of $1 \%$ were selected. The samples and both controls were applied to the chorioallantoic membrane in a volume of $600 \mu \mathrm{L}$, to cover the entire surface of the membrane, and the effects were uniform throughout the vascular plexus. After application of the samples, the vascular effects (hemorrhage, lysis, and vascular coagulation) were monitored for a period of five minutes using a steromicroscope (Discovery 8 Stereomicroscope, Zeiss, Göttingen, Germany). Before and five minutes after the application of the samples, photographs of the membrane were taken using Axio CAM 105 color, Zeiss, and these were then processed using ImageJ v 1.50e program (US National Institutes of Health, Bethesda, MD, USA). Finally, the irritating effect was quantified by applying the mathematical formula previously described by Batista-Duharte [49] and applied in our previous studies [50].

$$
I S=5 \times \frac{301-H}{300}+7 \times \frac{301-L}{300}+9 \times \frac{301-C}{300}
$$

The value of the irritation score provides a classification of the substances, as follows: (i) non-irritating substances (IS = 0-0.9); (ii) irritating substances (IS-1-8.9); and (iii) strongly irritating substances (IS $=9-21$ ) [51].

\subsection{Statistical Analysis}

The experimental data are presented as means \pm SD. The differences between data were compared by performing the one-way ANOVA analysis and Dunett's multiple comparisons post-test. The used software was GraphPad Prism version 9.0.0 for Windows (GraphPad Software, San Diego, CA, USA, www.graphpad.com, accessed on 10 November 2021). The statistically significant differences between data were labeled with * $\left({ }^{*} p<0.1\right.$; $\left.{ }^{* *} p<0.01 ;{ }^{* * *} p<0.001 ;{ }^{* * *} p<0.0001\right)$. 


\section{Conclusions}

The main objective of the current study was to investigate the chemical composition and in vitro efficiency in human colorectal adenocarcinoma cells of essential oils derived from H. rhamnodies L., C. citratus (D.C.) Stapf, and O. basilicum L. species. The data indicate the presence of active phytocompounds (estragole the main compound identified in $\mathrm{Hr} \_\mathrm{EO}$ and $\mathrm{Ob} \_E O$, alpha and beta-citral the main compounds from Cc_EO) with a potent EOdependent in vitro anti-CRC activity at high concentrations. In summary, all EOs decreased the viability and reduced the confluence; Hr_EO and CC_EO exerted the most potent antimigratory effect, while all samples induced apoptotic specific nuclear features in CRC cells. Furthermore, the results obtained indicate that these essential oils have a relatively low impact on the chorioallantoic membrane, which indicates that these substances exhibit a high biosafety and tolerance profile in the vascular plexus. Further studies, also on other intestinal cells, will be performed to simultaneously examine cell-specific markers and apoptosis indicators and to deepen the mechanisms involved in the anti-tumor efficacy of the studied EOs.

Author Contributions: Conceptualization, I.M., I.P. (Iulia Pinzaru) and C.A.D.; data curation, R.B., G.A.P., D.N. and I.P. (Iuliana Popescu); formal analysis, R.B., F.O., G.A.P., D.N. and I.P. (Iuliana Popescu); funding acquisition, O.M.C.; investigation, A.D. (Alina Dolghi), G.A.P., I.M. and I.P. (Iuliana Popescu); methodology, A.D. (Alina Dolghi), G.A.P., I.M. and I.P. (Iuliana Popescu); project administration, A.D. (Amadeus Dobrescu), I.P. (Iulia Pinzaru), O.M.C. and C.A.D.; resources, R.B., D.N. and O.M.C.; software, A.D. (Amadeus Dobrescu), F.O., D.N. and O.M.C.; supervision, A.D. (Amadeus Dobrescu), I.P. (Iulia Pinzaru) and C.A.D.; validation, A.D. (Alina Dolghi), A.D. (Amadeus Dobrescu), F.O. and I.M.; Visualization, R.B.; writing—original draft, A.D. (Alina Dolghi) and F.O.; writing - review and editing, I.P. (Iulia Pinzaru) and C.A.D. All authors have read and agreed to the published version of the manuscript.

Funding: This research was partially funded by the Romanian Ministry of Education and Research, the National Council for the Financing of Higher Education, grant number CNFIS-FDI-2021-0498.

Data Availability Statement: Data presented in this study are available on request from the first author.

Conflicts of Interest: The authors declare no conflict of interest.

\section{References}

1. WHO. Source: Globocan 2020. Available online: https://gco.iarc.fr/today/online-analysis-multi-bars?v=2020\&mode= cancer\&mode_population $=$ countries\&population $=900 \&$ population $=900 \& k e y=a s r \& s e x=0 \&$ cancer $=39 \&$ type $=0 \&$ statistic $=$ $5 \&$ prevalence $=0 \&$ population_group $=0 \&$ ages_group $\% 5 \mathrm{~B} \% 5 \mathrm{D}=0$ \&ages_group $\% 5 \mathrm{~B} \% 5 \mathrm{D}=17 \& \mathrm{kn} \_$items $=10 \&$ group_cancer $=1 \&$ include_nmsc $=1 \&$ include_nmsc_other=1\&type_multiple= $\% 257 \mathrm{~B} \% 2522$ inc $\% 2522 \% 253$ Atrue $\% 252 \mathrm{C} \% 2522 \mathrm{mort} \% 2522 \% 253$ Afalse $\% 252 \mathrm{C} \% 2522 \mathrm{prev} \% 2522 \% 253$ Afalse $\% 257 \mathrm{D} \&$ orientation=horizontal\&type_sort=0\&type_nb_items=\%257B\%2522top\%25 $22 \% 253$ Atrue $\% 252$ C $\% 2522$ bottom $\% 2522 \% 253$ Afalse $\% 257 \mathrm{D}$ (accessed on 21 September 2021).

2. Li, W.; Li, C.; Zheng, H.; Chen, G.; Hua, B. Therapeutic targets of traditional Chinese medicine for colorectal cancer. J. Tradit. Chin. Med. 2016, 36, 243-249. [PubMed]

3. Mármol, I.; Sánchez-de-Diego, C.; Dieste, A.P.; Cerrada, E.; Yoldi, M.J.R. Colorectal carcinoma: A general overview and future perspectives in colorectal cancer. Int. J. Mol. Sci. 2017, 18, 197. [CrossRef] [PubMed]

4. Papamichael, D.; Audisio, R.A.; Glimelius, B.; de Gramont, A.; Glynne-Jones, R.; Haller, D.; Köhne, C.H.; Rostoft, S.; Lemmens, V.; Mitry, E.; et al. Treatment of colorectal cancer in older patients: International Society of Geriatric Oncology (SIOG) consensus recommendations 2013. Ann. Oncol. 2015, 26, 463-476. [CrossRef]

5. Soreide, K.; Berg, M.; Skudal, B.S.; Nedreboe, B.S. Advances in the understanding and treatment of colorectal cancer. Discov. Med. 2011, 12, 393-404. [PubMed]

6. Dehelean, C.A.; Marcovici, I.; Soica, C.; Mioc, M.; Coricovac, D.; Iurciuc, S.; Cretu, O.M.; Pinzaru, I. Plant-derived anticancer compounds as new perspectives in drug discovery and alternative therapy. Molecules 2021, 26, 1109. [CrossRef]

7. Zhao, Y.; Hu, X.; Zuo, X.; Wang, M. Chemopreventive effects of some popular phytochemicals on human colon cancer: A review. Food Funct. 2018, 9, 4548-4568. [CrossRef] [PubMed]

8. Russo, R.; Corasaniti, M.T.; Bagetta, G.; Morrone, L.A. Exploitation of cytotoxicity of some essential oils for translation in cancer therapy. Evid.-Based Complement. Altern. Med. 2015, 2015, 397821. [CrossRef] [PubMed]

9. Spisni, E.; Petrocelli, G.; Imbesi, V.; Spigarelli, R.; Azzinnari, D.; Sarti, M.D.; Campieri, M.; Valerii, M.C. Antioxidant, antiinflammatory, and microbial-modulating activities of essential oils: Implications in colonic pathophysiology. Int. J. Mol. Sci. 2020, 21, 4152. [CrossRef] 
10. Kopustinskiene, D.M.; Jakstas, V.; Savickas, A.; Bernatoniene, J. Flavonoids as Anticancer Agents. Nutrients. $2020,12,457$. [CrossRef] [PubMed]

11. Yue, X.F.; Shang, X.; Zhang, Z.J.; Zhang, Y.N. Phytochemical composition and antibacterial activity of the essential oils from different parts of sea buckthorn (Hippophae rhamnoides L.). J. Food Drug Anal. 2017, 25, 327-332. [CrossRef] [PubMed]

12. Wang, H.; Gao, T.; Du, Y.; Yang, H.; Wei, L.; Bi, H.; Ni, W. Anticancer and immunostimulating activities of a novel homogalacturonan from Hippophae rhamnoides L. berry. Carbohydr. Polym. 2015, 131, 288-296. [CrossRef]

13. Zhamanbaeva, G.T.; Murzakhmetova, M.K.; Tuleukhanov, S.T.; Danilenko, M.P. Antitumor activity of ethanol extract from Hippophae rhamnoides L. leaves towards human acute myeloid leukemia cells in vitro. Bull. Exp. Biol. Med. 2014, 158, 252-255. [CrossRef]

14. Guo, R.; Guo, X.; Li, T.; Fu, X.; Liu, R.H. Comparative assessment of phytochemical profiles, antioxidant and antiproliferative activities of Sea buckthorn (Hippophaë rhamnoides L.) berries. Food Chem. 2017, 221, 997-1003. [CrossRef]

15. Grey, C.; Widén, C.; Adlercreutz, P.; Rumpunen, K.; Duan, R.D. Antiproliferative effects of sea buckthorn (Hippophae rhamnoides L.) extracts on human colon and liver cancer cell lines. Food Chem. 2010, 120, 1004-1010. [CrossRef]

16. Shah, G.; Shri, R.; Panchal, V.; Sharma, N.; Singh, B.; Mann, A.S. Scientific basis for the therapeutic use of Cymbopogon citratus, stapf (Lemon grass). J. Adv. Pharm. Technol. Res. 2011, 2, 3-8. [CrossRef] [PubMed]

17. Gomes, L.F.; Longhi, P.J.H.; Machado, L.; da Cruz, I.B.M.; Montano, M.A.E.; Martins, M.; Machado, S.A.; Steffani, J.A.; Cadoná, F.C. Lemongrass (Cymbopogon citratus (D.C.) Stapf) presents antitumoral effect and improve chemotherapy activity in prostate cancer cells. Anticancer Agents Med. Chem. 2021, 21, 1-21. [CrossRef]

18. Halabi, M.F.; Sheikh, B.Y. Anti-proliferative effect and phytochemical analysis of Cymbopogon citratus extract. Biomed. Res. Int. 2014, 2014, 906239. [CrossRef]

19. Sestili, P.; Ismail, T.; Calcabrini, C.; Guescini, M.; Catanzaro, E.; Turrini, E.; Layla, A.; Akhtar, S.; Fimognari, C. The potential effects of Ocimum basilicum on health: A review of pharmacological and toxicological studies. Expert Opin. Drug Metab. Toxicol. 2018, 14, 679-692. [CrossRef] [PubMed]

20. Costea, T.; Hudiță, A.; Ciolac, O.A.; Gălățeanu, B.; Ginghină, O.; Costache, M.; Ganea, C.; Mocanu, M.M. Chemoprevention of colorectal cancer by dietary compounds. Int. J. Mol. Sci. 2018, 19, 3787. [CrossRef]

21. Redondo-Blanco, S.; Fernández, J.; Gutiérrez-del-Río, I.; Villar, C.J.; Lombó, F. New insights toward colorectal cancer chemotherapy using natural bioactive compounds. Front. Pharmacol. 2017, 8, 109-131. [CrossRef]

22. Patel, S.; Gogna, P. Tapping botanicals for essential oils: Progress and hurdles in cancer mitigation. Ind. Crop. Prod. 2015, 76, 1148-1163. [CrossRef]

23. Gagnon, M.; Zihler Berner, A.; Chervet, N.; Chassard, C.; Lacroix, C. Comparison of the Caco-2, HT-29 and the mucus-secreting HT29-MTX intestinal cell models to investigate Salmonella adhesion and invasion. J. Microbiol. Methods 2013, 94, 274-279. [CrossRef] [PubMed]

24. Levorato, S.; Dominici, L.; Fatigoni, C.; Zadra, C.; Pagiotti, R.; Moretti, M.; Villarini, M. In vitro toxicity evaluation of estragolecontaining preparations derived from Foeniculum vulgare Mill. (fennel) on HepG2 cells. Food Chem. Toxicol. 2018, 111, 616-622. [CrossRef] [PubMed]

25. Alves Júnior, E.B.; de Oliveira Formiga, R.; de Lima, S.C.A.; Araruna, C.M.E.; de Souza Pessoa, M.L.; Vasconcelos, R.C.; Gomes de Carvalho, T.; Gonçalves de Jesus, T.; Antunes Araújo, A.; Fernandes, R.; et al. Estragole prevents gastric ulcers via cytoprotective, antioxidant and immunoregulatory mechanisms in animal models. Biomed. Pharmacother. 2020, 130, 110578. [CrossRef] [PubMed]

26. Olsson, M.E.; Gustavsson, K.E.; Andersson, S.; Nilsson, Å.; Duan, R.D. Inhibition of cancer cell proliferation in vitro by fruit and berry extracts and correlations with antioxidant levels. J. Agric. Food Chem. 2004, 52, 7264-7271. [CrossRef] [PubMed]

27. Kapur, A.; Felder, M.; Fass, L.; Kaur, J.; Czarnecki, A.; Rathi, K. Modulation of oxidative stress and subsequent induction of apoptosis and endoplasmic reticulum stress allows citral to decrease cancer cell proliferation. Sci. Rep. 2016, 6, 27530-27544. [CrossRef] [PubMed]

28. Nigjeh, S.E.; Yeap, S.K.; Nordin, N.; Kamalideghan, B.; Ky, H.; Rosli, R. Citral induced apoptosis in MDA-MB-231 spheroid cells. BMC Complement. Altern. Med. 2018, 18, 1-18. [CrossRef] [PubMed]

29. Balusamy, S.R.; Ramani, S.; Natarajan, S.; Kim, Y.J.; Perumalsamy, H. Integrated transcriptome and in vitro analysis revealed anti-proliferative effect of citral in human stomach cancer through apoptosis. Sci. Rep. 2019, 9, 4883. [CrossRef] [PubMed]

30. Balusamy, S.R.; Perumalsamy, H.; Veerappan, K.; Huq, M.A.; Rajeshkumar, S.; Lakshmi, T. Citral induced apoptosis through modulation of key genes involved in fatty acid biosynthesis in human prostate cancer cells: In silico and in vitro study. Biomed. Res. Int. 2020, 2020, 6040727. [CrossRef] [PubMed]

31. Ruvinov, I.; Nguyen, C.; Scaria, B.; Vegh, C.; Zaitoon, O.; Baskaran, K.; Mehaidli, A.; Nunes, M.; Pandey, S. Lemongrass extract possesses potent anticancer activity against human colon cancers, inhibits tumorigenesis, enhances efficacy of FOLFOX, and reduces its adverse effects. Integr. Cancer Ther. 2019, 18, 1-13. [CrossRef] [PubMed]

32. Fitsiou, E.; Mitropoulou, G.; Spyridopoulou, K.; Tiptiri-Kourpeti, A.; Vamvakias, M.; Bardouki, H.; Panayiotidis, M.I.; Galanis, A.; Kourkoutas, Y.; Chlichlia, K.; et al. Phytochemical profile and evaluation of the biological activities of essential oils derived from the Greek aromatic plant species Ocimum basilicum, Mentha spicata, Pimpinella anisum and Fortunella margarita. Molecules 2016, 21, 1069. [CrossRef] [PubMed]

33. Anthony, J.-P.; Fyfe, L.; Smith, H. Plant active components-A resource for antiparasitic agents? Trends Parasitol. 2005, 21, 462-468. [CrossRef] 
34. Wang, B.; Lin, L.; Ni, Q.; Su, C.L. Hippophae rhamnoides Linn. for treatment of diabetes mellitus: A review. J. Med. Plants Res. 2011, 5, 2599-2607.

35. Kimutai, A.; Ngeiywa, M.; Mulaa, M.; Njagi, P.G.N.; Ingonga, J.; Nyamwamu, L.B.; Ombati, C.; Ngumbi, P. Repellent effects of the essential oils of Cymbopogon citratus and Tagetes minuta on the sandfly, Phlebotomus duboscqi. BMC Res. Notes 2017, 10, 1-10. [CrossRef] [PubMed]

36. Faur, A.; Watz, C.; Moacă, E.A.; Avram, Ş.; Borcan, F.; Pinzaru, I.; Iftode, A.; Nicolov, M.; Popovici, R.A.; Raica, M.; et al. Correlations on phenolic screening related to in vitro and in ovo assessment of Ocimum basilicum, L. hydro-alcoholic extracts used as skin active ingredient. Molecules 2020, 25, 5442. [CrossRef] [PubMed]

37. Olas, B.; Skalski, B.; Ulanowska, K. The anticancer activity of sea buckthorn [Elaeagnus rhamnoides (L.) A. Nelson]. Front. Pharmacol. 2018, 9, 232-240. [CrossRef]

38. Upadhyay, N.K.; Kumar, R.; Mandotra, S.K.; Meena, R.M.; Siddiqu, M.S.; Sawhney, R.C.; Gupta, A. Safety and wound healing efficacy of sea buckthorn (Hippophae rhamnoides L.) seed oil in experimental rats. Food Chem. Toxicol. 2009, 47, 1146-1153. [CrossRef] [PubMed]

39. Kumar, R.; Kumar, G.P.; Chaurasia, O.P.; Singh, S. Phytochemical and pharmacological profile of seabuckthorn oil: A review. Res. J. Med. Plants 2011, 5, 491-499. [CrossRef]

40. Bidinotto, L.T.; Costa, C.A.; Costa, M.; Rodrigues, M.A.; Barbisan, L.F. Modifying effects of lemongrass essential oil on specific tissue response to the carcinogen N-methyl-N-nitrosurea in female BALB/c mice. J. Med. Food 2012, 15, 161-169. [CrossRef] [PubMed]

41. Nguyen, C.; Mehaidli, A.; Baskaran, K.; Grewal, S.; Pupulin, A.; Ruvinov, I.; Scaria, B.; Parashar, K.; Vegh, C.; Pandey, S. Dandelion root and lemongrass extracts induce apoptosis, enhance chemotherapeutic efficacy, and reduce tumour xenograft growth in vivo in prostate cancer. Evid.-Based Complement. Altern. Med. 2019, 2019, 2951428. [CrossRef] [PubMed]

42. Aruna, K.; Sivaramakrishnan, V.M. Plant products as protective agents against cancer. Ind. J. Exp. Biol. 1990, 28, $1008-1011$.

43. Rodrigues, L.B.; Brito Pereira Bezerra Martins, O.A.; Cesário, F.R.; Castro, F.F.E.; de Albuquerque, T.R.; Martins Fernandes, M.N.; Fernandes da Silva, B.A.; Quintans Júnior, L.J.; da Costa, J.G.; Coutinho, H.D.M.; et al. Anti-inflammatory and antiedematogenic activity of the Ocimum basilicum essential oil and its main compound estragole: In vivo mouse models. Chem. Biol. Interact. 2016, 257, 14-25. [CrossRef] [PubMed]

44. Sumalan, R.M.; Alexa, E.; Popescu, I.; Negrea, M.; Radulov, I.; Obistioiu, D.; Cocan, I. Exploring ecological alternatives for crop protection using coriandrum sativum essential oil. Molecules 2019, 24, 2040. [CrossRef] [PubMed]

45. Guran, K.; Buzatu, R.; Pinzaru, I.; Boruga, M.; Marcovici, I.; Coricovac, D.; Avram, S.; Poenaru, M.; Susan, M.; Susan, R.; et al. In vitro pharmaco-toxicological characterization of Melissa officinalis total extract using oral, pharynx and colorectal carcinoma cell lines. Processes 2021, 9, 850. [CrossRef]

46. Xu, C.; Sun, G.; Yuan, G.; Wang, R.; Sun, X. Effects of platycodin D on proliferation, apoptosis and PI3K/Akt signal pathway of human glioma U251 cells. Molecules 2014, 19, 21411-21423. [CrossRef] [PubMed]

47. Pinzaru, I.; Chioibas, R.; Marcovici, I.; Coricovac, D.; Susan, R.; Predut, D.; Georgescu, D.; Dehelean, C. Rutin exerts cytotoxic and senescence-inducing properties in human melanoma cells. Toxics 2021, 9, 226. [CrossRef]

48. Farcas, G.C.; Dehelean, C.; Pinzaru, I.A.; Mioc, M.; Socoliuc, V.; Moaca, E.A.; Avram, S.; Ghiulai, R.; Coricovac, D.; Pavel, I.; et al. Thermosensitive betulinic acid-loaded magnetoliposomes: A promising antutumor potential for highly aggressive human breast adenocarcinoma cells under hyperthermic conditions. Int. J. Nanomed. 2020, 15, 8175-8200. [CrossRef] [PubMed]

49. Batista-Duharte, A.; Jorge Murillo, G.; Pérez, U.M.; Tur, E.N.; Portuondo, D.F.; Martínez, B.T.; Téllez-Martínez, D.; Betancourt, J.E.; Pérez, O. The hen's egg test on chorioallantoic membrane: An alternative assay for the assessment of the irritating effect of vaccine adjuvants. Int. J. Toxicol. 2016, 35, 627-633. [CrossRef] [PubMed]

50. Hut, E.-F.; Radulescu, M.; Pilut, N.; Macasoi, I.; Berceanu, D.; Coricovac, D.; Pinzaru, I.; Cretu, O.; Dehelean, C. Two antibiotics, ampicillin and tetracycline, exert different effects in HT-29 colorectal adenocarcinoma cells in terms of cell viability and migration capacity. Curr. Oncol. 2021, 28, 2466-2480. [CrossRef] [PubMed]

51. Budai, P.; Kormos, É.; Buda, I.; Somody, G.; Lehel, J. Comparative evaluation of HET-CAM and ICE methods for objective assessment of ocular irritation caused by selected pesticide products. Toxicol. Vit. 2021, 74, 105150. [CrossRef] [PubMed] 